\title{
外リンパ瘻症例に和ける臨床経過の検討
}

\author{
関聡・犬飼 賢也・渡辺一道・橋本 茂久 \\ 山本裕・佐藤斎・高橋姿
}

\section{Comparision of the Clinical Course between Cases of Perilymph Fistula Treated Surgically and Conservatively}

\author{
Satoshi Seki, Kenya Inukai, Kazumichi Watanabe, Shigehisa Hashimoto, \\ Yutaka Yamamoto, Hitoshi Sato and Sugata Takahashi \\ (Niigata University)
}

\begin{abstract}
Five cases of perilymph fistula (PLF) were classified into two groups: three cases of PLF identified surgically (confirmed group), and two cases treated conservatively (uncertain group). The recovery of hearing and the outcome of nystagmus between the groups were compared. In both groups, the improvement of hearing in the low-middle tone range was good, but that in the high tone range was poor. In the confirmed group, spontaneous and positional nystagmus decreased or diminished soon after the closure operation of PLF. On the other hand, in the uncertain group, both types of nystagmus continued for long periods. We considerd that some inner ear damage remained in this group. Furthermore, PLF was indicated if spontaneous or positional nystagmus persisted for long periods without vertigo in idiopathic sudden hearing loss or Ménière's disease.
\end{abstract}

Key words : perilymph fistula, surgically, conservatively, hearing, nystagmus

はじめに

外リンパ瘦の診断は試験的鼓室開放術により外リンパ の漏出を確認することで確定する。しかし症例の中には 外リンパ瘦が強く疑われるものの, 安静と突発性難聴に 準じた点滴治療で難聴，めまいが自然に回復する症例も みられる.このよらな症例では本当に外リンパ瘦が存在 していたのか，あるいは瘦孔が自然閉鎖したのかという 疑問が残る。そこで今回われわれは最近経験した外リン パ瘦確実例と疑い例との聴力ならびに眼振の経過につい て比較検討し，若干の知見を得たので報告する。

\section{症例}

【外リンパ瘻確実例】

症例 $1: 48$ 歳, 女性.

主訴 : 右耳鳴, 右難聴.
既往歷, 家族歴 : 特記すべき事項なし.

現病歴：1998年 1 月 2 日安静時誘因なく突然右耳鳴が 出現した。1月 8 日近医耳鼻科受診し，血管拡張剤，ビ タミン剤等の内服治療を開始したが，聴力の変動がみら れたため(図 1)，3月10日 (発症68日目)当科紹介された. めまいは自覚していない。

現症 : 局所所見に特記すべきことはなく，純音聴力検 査で $70 \mathrm{dBHL}$ ( 3 分法平均)の右感音難聴を認め, 安静 仰臥位 60 分後では低周波数域で $10 \mathrm{dBHL}$ 以上の改善を

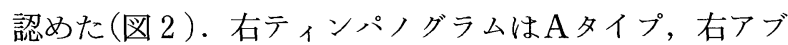
ミ骨筋反射は陰性, 右自記オージオグラムは $500 \mathrm{~Hz}$, $2000 \mathrm{~Hz}$ で Jerger II 型, 右 SISI 検査は $2000 \mathrm{~Hz}$ で陽性 であった．平衡機能検査では，右向き水平・回旋混合性 自発・頭位眼振があり，右 Hennebert sign は陽性，振 子様回転検査では右迷路優位を認め，視標追跡検査に異 


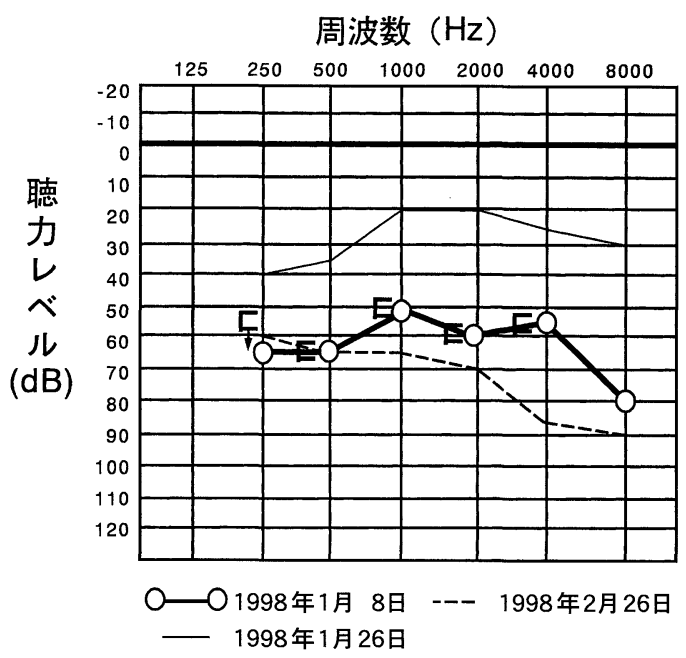

図 1 当科受診前の聴力経過 (症例 1)

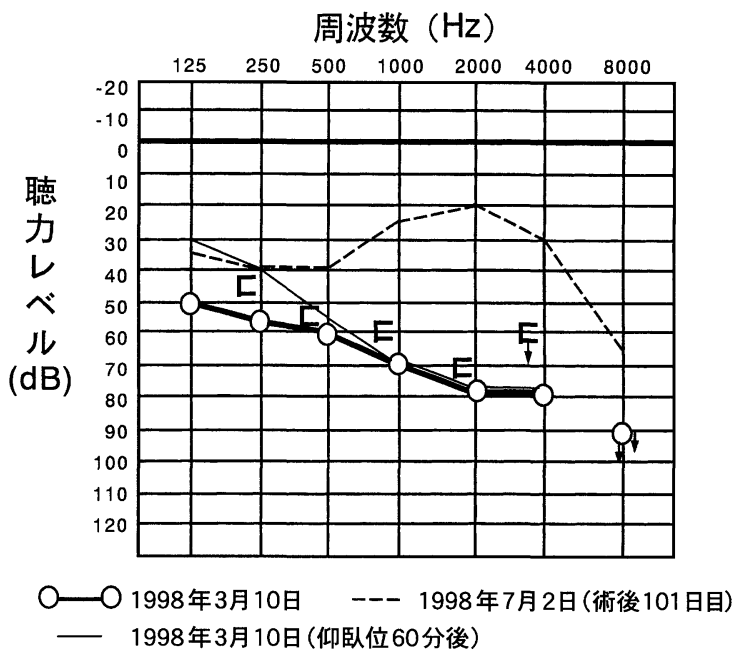

図 2 当科での聴力経過 (症例 1)

常はみられなかった．耳X線，CT，MRI 検査にも異常 所見はなかった。

経過：右外リンパ癭を疑い，3 月23日(発症81日目)耳 内法により試験的鼓室開放術を施行した。術中約10分間 の頭部低位にて前庭空ならびに蝸牛空からともに外リン 八゚液と思われる漏出を認めたため, 両空周囲の粘膜を除 去後耳珠軟骨膜を用いて瘦孔閉鎖術を行った。術後60日 目 (発症141日目)自発・頭位眼振は消失, 101日目 (発症 182 日目) 聴力は $28 \mathrm{dBHL}$ (3 分法平均) 飞改善した(図 2 ).

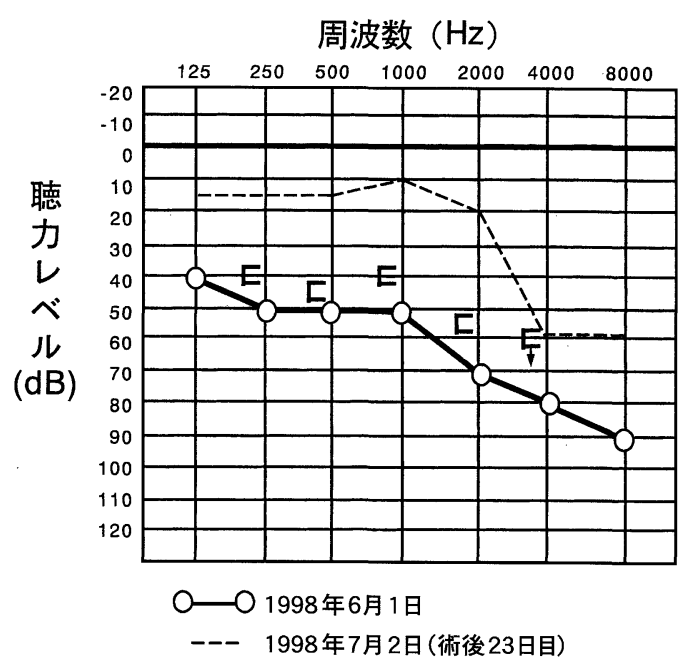

図 3 症例 2 の聴力経過

症例 $2: 6$ 歳, 男児.

主訴：めまい, 右難聴.

既往歷，家族歴：特記すべき事項なし。

現病歴：1998年 5 月 26 日自転車より転倒し右側頭部を 強打, 翌日よりめまい，右難聴が出現したため，近医脳 外科を受診した. 頭部 X線, CT 検查, 神経学的所見に 異常はみられなかったが，30日より右難聴を自覚したた め，6月 1 日(発症 7 日目)当科紹介された.

現症：局所所見に特記すべさことはなく, 純音聴力検 査で $57 \mathrm{dBHL}$ ( 3 分法平均)の右感音難聴(図 3 ), 右ティ ンパノグラムは Aタイプ, 右アブミ骨筋反射は陰性で あった。平衡機能検査では, 左向き水平・回旋混合性自 発・頭位眼振があり, 右 Hennebert sign は陰性, 振子 様回転検査では左迷路優位を認め, 視標追跡検査に異常 はみられなかった。

経過：右外リンパ瘦を疑い，6月10日(発症16日目)耳 内法により試験的鼓室開放術を施行した。アブミ骨底板 に骨折線を認め，同部より外リンパ液の漏出がみられた。 底板周囲の粘膜を剥離し耳珠軟骨膜を用いて瘦孔閉鎖術 を行った。術後23日目(発症39日目)飞は聴力は 15 $\mathrm{dBHL}$ ( 3 分法平均) 飞改善し(図 3 ), めまい屯消失し た. 術後 80 日目 (発症 96 日目)には明らかな眼振もみられ なくなった。

症例 $3: 50$ 歳, 男性.

主訴 : 左難聴.

既往歴: 糖尿病で内服加療中. 
家族歴 : 父が糖尿病.

現病歴: 1998年 9 月 2 日耳閉感があり耳抜きをした直 後, 回転性めまい, 左難聴が出現した. 9 月 3 日近医耳 鼻科に入院, ステロイド, 血管拡張剂ならびにビタミン 剤の点滴治療を行うも左聴力の変動がみられ(図 4), 9 月21日(発症 20 日目)当科に転院となった.

現症 : 局所所見に特記すべきことはなく, 純音聴力検 查で $35 \mathrm{dBHL}$ (3 分法平均) の左感音難聴(図 4 ), 左テ1 ンパノグラムはAタイプ, 左アブミ骨筋反射は陽性, 左 SISI 検査は $500 \mathrm{~Hz}, 2000 \mathrm{~Hz}$ で陽性であった. 平衡機 能検査では, 右向き水平・回旋混合性自発・頭位眼振, 振子様回転検査では右迷路優位を認め, 視標追跡検査に 異常はみられなかった。耳 X線, CT 検査にも異常所見 はなかった。

経過 : 左外リンパ㾇を疑い, 9 月28日(発症27日目)耳 内法により試験的鼓室開放術を施行した. 蝸牛空から外 リンパ液と思われる漏出を認めたため, 耳珠軟骨膜を用 いて瘦孔閉鎖術を行った。術後15日目 (発症42日目)には 自発・頭位眼振は消失, 24 日目 (発症51日目)聴力は 25 $\mathrm{dBHL}$ ( 3 分法平均) 飞改善し安定した (図 4 ).

\section{【外リンパ瘦疑い例】}

症例 $4: 59$ 歳, 女性.

主訴 : 右耳鳴, 右難聴.

既往歴：1993年 6 月交通事故で後頭部打撲.

家族歴：特記すべき事項なし.

現病歴：1997年11月12日くしゃみをした後, 右耳鳴が
出現, 18日になって右難聴も自覚したため，20日(発症 9 日目)当科を受診した。 めまいはみられなかった。

現症 : 局所所見に特記すべさことはなく, 純音聴力検 查で $85 \mathrm{dBHL}$ ( 3 分法平均) の右混合難聴 (図 5 ), 右ティ ンパノグラムは Aタイプ, 右アブミ骨筋反射は陽性, 右 SISI 検查は $500 \mathrm{~Hz}, 2000 \mathrm{~Hz}$ で陽性であった．平衡機 能検査では, 右向き水平・回旋混合性自発・頭位眼振, 振子様回転検査では右迷路優位を認めた．視運動性眼振 検査, 視標追跡検査に異常はみられなかった. 耳X線, CT, MRI 検査にも異常所見はなかった.

経過: 右外リンパ㾇を疑い11月20日〜12月19日入院の 上，安静ならびに突発性難聴に準じたステロイド，血管 拡張剂ならびにビタミン剂の点滴加療を行い，12月18日 (発症37日目)聴力は $18 \mathrm{dBHL}$ (3 分法平均)まで改善し たが(図 5 ), 1998年 3 月 5 日(発症114日目)になっても 右向き水平・回旋混合性自発・頭位眼振は不変で, 1 年 後の12月 3 日減少はしたが残存している.

症例 $5: 42$ 歳, 男性.

主訴：右耳鳴, 右難聴.

既往歴, 家族歴 : 特記すべき事項なし.

現病歴：1998年 2 月 9 日耳閉感があり耳抜きをした直 後, 右耳鳴, 右難聴が出現した. 10日近医耳鼻科受診し, 12 日(発症 4 日目)当科紹介された。 めまいはみられな かった.

現症 : 局所所見に特記すべさことはなく, 純音聴力検 查で $48 \mathrm{dBHL}$ ( 3 分法平均) の右感音難聴 (図 6 ), 右テ 1

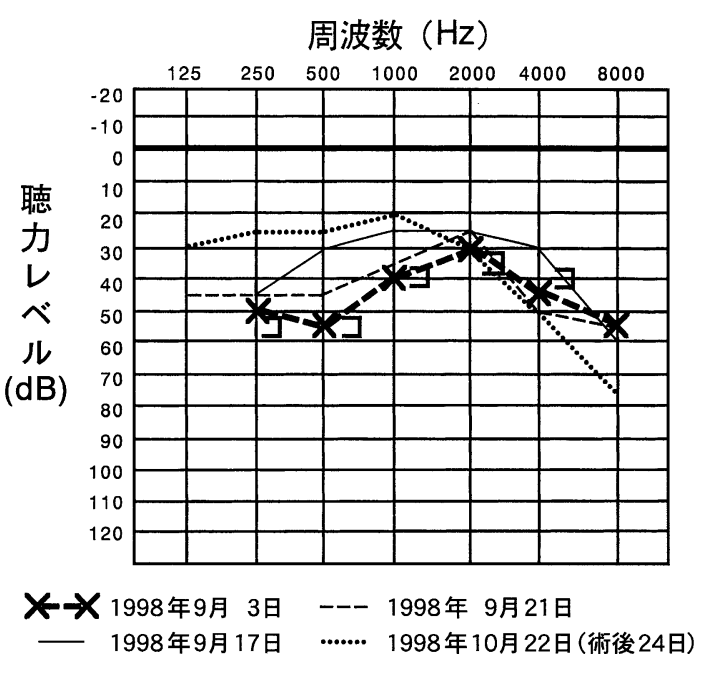

図 4 症例 3 の聴力経過

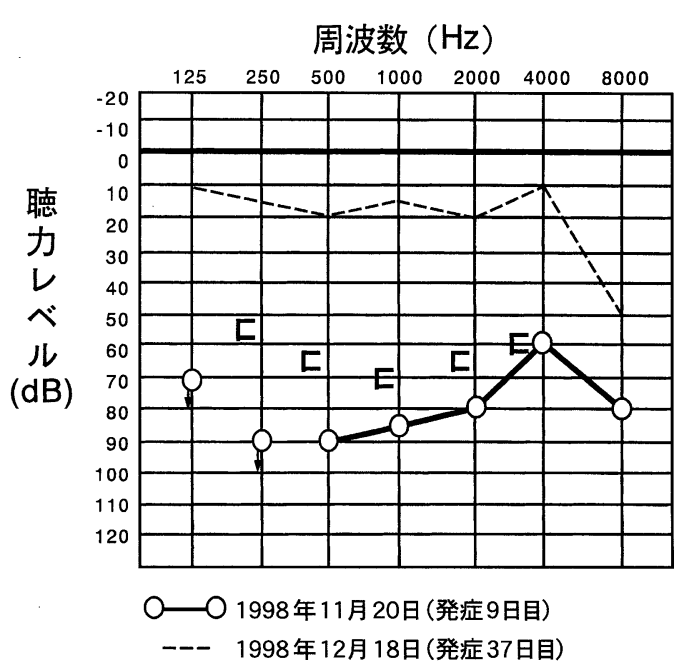

図 5 症例 4 の聴力経過 


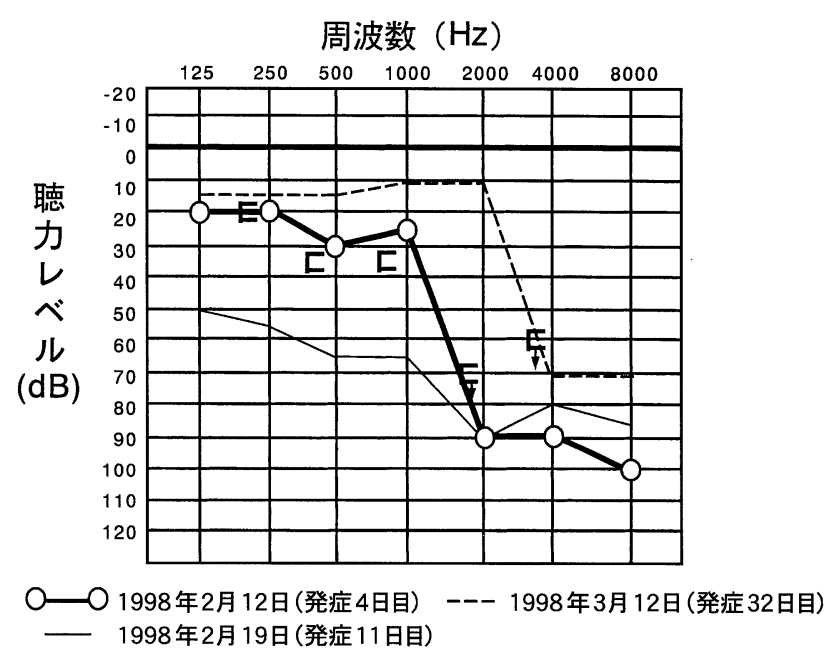

図 6 症例 5 の聴力経過

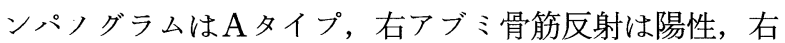
自記オージオグラムは $1000 \mathrm{~Hz}$ で Jerger II 型, 右 SISI 検査は $1000 \mathrm{~Hz}$ で陰性であった。平衡機能検査では, 右向き水平性自発・頭位眼振, 右 Hennebert sign は陽 性であった。温度刺激検查, 振子様回転検査, 視運動性 眼振検查, 視標追跡検查に異常はみられなかった. 耳X 線, CT 検査にも異常所見はなかった.

経過 : 右外リンパ瘦を疑い当科外来にて突発性難聴に 準じたステロイド，血管拡張剤ならびにビタミン剤の点 滴治療を行うも, 右聴力はさらに低下したため(図 6 ), 2 月 20 日入院となった。 3 月 8 日(発症28日目)まで安静 の上, 点滴治療を行い聴力は $12 \mathrm{dBHL}$ ( 3 分法平均) で改善したが(図 6 )，4月 9 日(発症60日目)になっても 右向き水平・回旋混合性自発・頭位眼振は不変で，9月 10日(発症214日目)でも滦滦同様であった。

全 5 症例の自発・頭位眼振を図 7 亿示す. 眼振の測定 には ENG 記録あるいは赤外線 CCD カメラを用いた。

\section{考察}

外リンパ癭の確定診断は試験的鼓室開放術の久である ため, 外リンパ瘦確実例について retrospective に病歴, 術前聴力や自発・頭位眼振, 温度刺激検査, 瘦孔症状な ぞの前庭所見を検討した報告は多(1) 10)。 をた試験的 鼓室開放術を行い，内耳空閉鎖術を施行した外リンパ瘦 確実例と疑い例の術後聴力やめまい症状の経過を検討し た報告も散見されるが22410), 自発・頭位眼振所見の予後
そついての報告は少ない。さらに試験的鼓室開放術を 行っていない外リンパ瘦疑い例では, 安静と突発性難聴 に準じた点滴治療のみで難聴, め屯いが回復してしまう 症例も又られるため, 自発・頭位眼振所見の予後につい てはほとんど検討されていない，そこで今回われわれは 最近経験した外リンパ瘦確実例と試験的鼓室開放術を 行っていない疑い例との聴力ならびに眼振所見の経過に ついて比較し検討を加えた.

聴力の経過では, 外リンパ瘦確実例 3 例とも $250 \sim 2000$ $\mathrm{Hz}$ の低・中周波数域の聴力はほぼ正常に回復したが, 高周波数域の $4000 \mathrm{~Hz}$ では不変あるいは軽度改善のみ で， $8000 \mathrm{~Hz}$ では不変あるいは悪化していた．外リンパ 瘻疑い例 2 例でも $250 \sim 2000 \mathrm{~Hz}$ の低・中周波数域の聴 力は注添正常に回復したものの, 高周波数域の $4000 \mathrm{~Hz}$ では回復と不変で, $8000 \mathrm{~Hz}$ ではともに不変であった。 小川ら ${ }^{9)}$ は外リンパ瘦手術症例に括いて，聴力の回復は 低・中周波数域に認められ，高周波数域の回復は不良で あるとし，深谷ら ${ }^{1)}$ も試験的鼓室開放術を行い，内耳空 閉鎖術を施行した外リンパ瘦確実例と疑い例の聴力変化 を検討し，聴力の改善は低周波数域で著明で，確実例と 疑い例で有意差はないと報告している. 今回の症例も， 確実例特よび疑い例とも低・中周波数域の聴力の改善は 著明であったが，高周波数域の聴力の改善は不良であっ た。すなわち試験的鼓室開放術を行わずに自然治癒した 疑い例も確実例に類似した聴力回復を認めた.

外リンパ㾞の手術時期は, 聴力の回復について突発性 


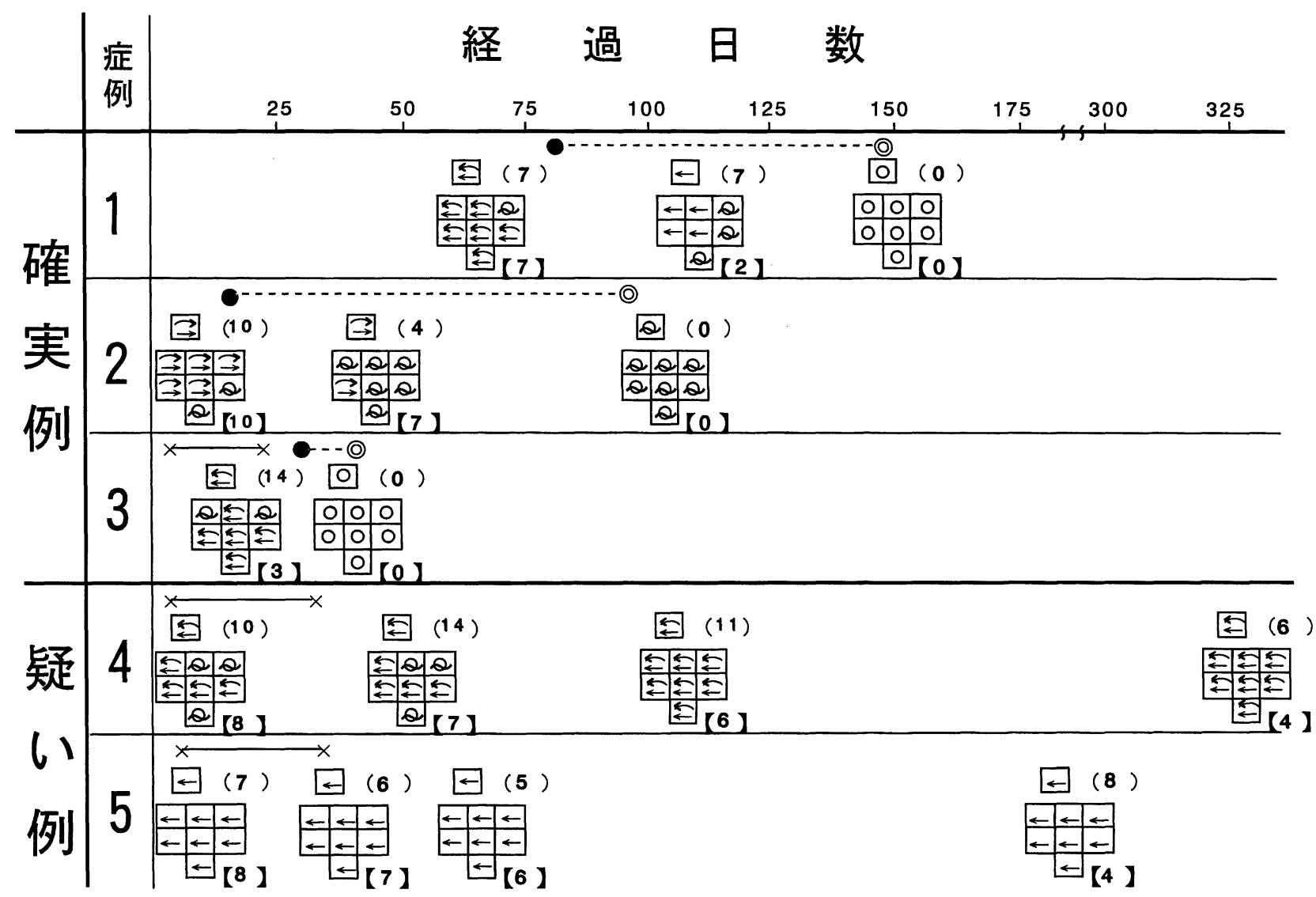

図 7 自発・頭位眼振所見の経過

○手術, @眼振消失, $\times$ 点滴開始および終了, ( ）自発眼振数 (個/10秒),【】患側下頭位眼振数(個/10秒)を示す.

難聴の自然治癒症例と外リンパ瘦手術成績を比較した検 討から発症30日以内が望ましいといわれているが3)，3 カ月以内でも ${ }^{811)}$ ， あるいは変動する聴力障害例11)であ れば手術により聴力が改善する可能性があるとの報告も ある. 今回の確実例では発症から試験的鼓室開放術まで 16日，27日，81日であったが，全例聴力が改善した. 外 リンパ瘦が疑われたら，30日以降でも試験的鼓室開放術 を試みるべきと思われた。

また外リンパ瘻疑い例は 2 例とも発症ほぼ30日前後に 聴力の改善がみられ, 自覚的にめまい症状もないため, 試験的鼓室開放術は行わなかった。このような症例では 病歴ならびに検査所見から強く外リンパ瘦が疑われたも のの，本当に外リンパ瘦が存在していたのかあるいは瘦 孔は自然閉鎖したのかといら疑問が残る。そこで眼振の 経過について外リンパ瘦確実例と比較検討したところ, 外リンパ瘻確実例では自発・頭位眼振は 3 例とも術後 15
日，60日，80日目でほ压消失した。一方外リンパ瘦疑い 例では 2 例とも発症後214日，344日の長期にわたり自発 ならびに頭位眼振はほとんど減少せずに持続していた。 すなわち外リンパ瘦疑い例では，聴力が改善しめまいの 自覚症状がないにもかかわらず眼振が長期にわたって持 続しているものがあり，なんらかの内耳障害が残存して いると考えられる．めまいの自覚症状は軽微な平衡障害 の評価には不適当であるとされて拉り 12$) ，$ 眼振検査など の他覚的評価も必ず施行すべきと思われた。

外リンパ瘦では常に突発性難聴やメニエール病との鑑 別が重要であるが3), 高橋ら ${ }^{12)}$ は突発性難聴45例の自発 眼振を経時的に観察した結果，発症 2 力月以降は全例で 自発眼振が消失したと報告している. 山中ら ${ }^{13)}$ はメ二 エール病の自然経過では，めまい発作扣よび自発眼振は 徐々に寛解し, 特にめまい発作 8 週後には自発眼振は注 ぼ寛解したと報告して抮り，また外リンパ瘦ではメニ 
エール病と比較してめまい発作寛解期にも頭位眼振が持 続しがちであるともいわれている14). 突発性難聴やメ二 エール病として経過観察している症例で，めまいの自覚 症状がないにもかかわらず，自発ならびに頭位眼振が持 続しているものは外リンパ瘦も念頭に执く必要があると 思われた. 今後は外リンパ瘦が強く疑われた症例のうち, 保存的治療で聴力の改善がみられなかった症例の眼振所 見にも検討を加えてみたい.

暁ら ${ }^{7)}$ は外リンパ瘦疑い症例に対する安静治療の重要 性を指摘している. 症例 5 では自宅での安静指示と外来 での点滴治療を行ったが，聴力の低下がみられたため入 院の上安静を遵守させ同様の点滴治療を行ったところ聴

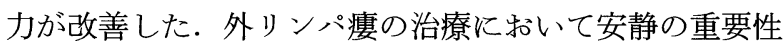
が再認識された。

\section{まとめ}

1. 外リンパ瘦確実例 3 例と疑い例 2 例の聴力ならび に自発・頭位眼振の経過について比較検討した。

2 . 外リンパ瘦確実例ならびに疑い例とも低・中周波 数域の聴力改善は著明であったが，高周波数域の聴力改 善は不良であった。

3. 外リンパ瘻確実例では術後早期に自発・頭位眼振 が消失あるいは減少したが，知い例では長期にわたり持 続して和り，何らかの内耳障害が残存している可能性が 示唆された.

4. 突発性難聴, メニエール病症例の中で，めまいが ないにもかかわらず自発・頭位眼振が長期にわたり持続 しているものは，外リンパ瘦を念頭に特くべきと思われ た。

\section{参考文献}

1 ) 深谷 卓, 野村恭也 : 外リンパ瘦, 病態と治療効果. Audiology Japan $31: 367 \sim 368,1988$.

2 ) 深谷 卓, 角田玲子, 畑 裕子：外リンパ瘦に扣ける聴覚 障害の予後. Audiology Japan 38 : 353 354, 1995.

3 ) 深谷卓, 野村恭也: 外リンパ瘦の臨床像 一文献的考 察一. 耳喉 $57: 271 \sim 278,1985$.

4 ) 浅野容子：外リンパ㿉の診断について一確実例と疑い例 の比較一. 耳展 $34: 411 \sim 425,1991$.

5 ) Seltzer S and MaCabe BF : Perilymph fistula; the Iowa experience. Laryngoscope $96: 37 \sim 49,1986$.

6 ) Shelton C and Simmons FB : Perilymph fistula; the Stanford experience. Ann Otol Rhiol Laryngol $97: 105$ $\sim 108,1988$.

7 ）暁 清文, 田所広文, 柳原尚明 : 内耳空破裂症の臨床像. 日耳鼻 $84 ：$ 975 982, 1981.

8 ）深谷 卓, 野村恭也 : 特発性外リンパ瘻の臨床像. 日耳鼻 $91: 233 \sim 239,1988$.

9 ）小川 郁, 神崎 亿, 小川茂雄, 他 : 外リンパ瘻の臨床像. Otol Jpn $1: 1 \sim 8,1991$.

10）北原 糺, 久保 武, 楢村裕美, 他：外リンパ瘦に括ける 平衡障害の予後 Equilibrium Res Suppl 9：98〜101, 1993.

11）水越鉄理：外リンパ㾇 一めまい. 平衡障害を中心に一. 耳鼻臨床 $83: 1630 \sim 1633,1990$.

12）高橋正紘，神崎 仁，猪 忠彦：突発性難聴の予後と平衡 機能検査所見 一自発眼振, 減衰振子様回転検査, 視標追 跡楧査所見を中心に一. 耳鼻臨床 $67: 541 〜 555,1974$.

13）山中敏彰, 藤田信哉, 松永 喬 : ニニール病めまい発作 の自然経過と治療効果判定一治療施行例を対照に一. Equilibrium Res Suppl $9: 108 \sim 115,1993$.

14）深谷 卓, 野村恭也 : 外リンパ瘻 一メニエール病との鑑 別診断一. 日耳鼻 $93: 2009 \sim 2013,1990$.

$\left(\begin{array}{l}\text { 原稿受付 : 平成 } 11 \text { 年 } 4 \text { 月 } 28 \text { 日 } \\ \text { 原稿採択 : 平成11年 } 6 \text { 月 } 9 \text { 日 } \\ \text { 別刷請求先 : 関 聡 } \\ \text { T } 951-8510 \text { 新潟市旭町通 } 1 \\ \text { 新潟大学耳鼻咽喉科学教室 }\end{array}\right)$

